\title{
FULL USAGE OF RECLAIMED ASPHALT CONCRETES AS BASES
}

\author{
Shisheng WU ${ }^{1}$, Yoshitaka HACHIYA ${ }^{2}$ and Koichi SUGIMOTO ${ }^{3}$ \\ ${ }^{1}$ Dr. Eng., STA Fellow, Airport Facility Laboratory, National Institute for Land and Infrastructure Management, \\ Ministry of Land, Infrastructure and Transport (1-1, Nagase 3, Yokosuka 239-0826, Japan) \\ ${ }^{2}$ Member of JSCE, Dr. Eng., Chief, Airport Facility Laboratory, National Institute for Land and Infrastructure \\ Management, Ministry of Land, Infrastructure and Transport \\ ${ }^{3}$ Technical Research Institute, Obayashi Road Corporation (2-12-36, Numakage, Urawa 336-0027, Japan)
}

\begin{abstract}
Recycling of asphalt concrete is increasingly used as a major rehabilitation method in Japan because it can conserve natural resources, reduce costs and save energy. In this study, reclaimed asphalt concrete from Tokyo International Airport was evaluated for use in four types of base materials: recycled granular material, recycled cement stabilized material, recycled cement-emulsified asphalt stabilized material and recycled hot-asphalt stabilized material. The results of laboratory tests indicated: 1) These materials can satisfy base course and subbase requirements, and 2) they are sensitive to temperature and water.
\end{abstract}

Key Words: Reclaimed asphalt pavement, base course, subbase, Tokyo International Airport

\section{BACKGROUND}

Old asphalt concrete is generated during most pavement resurfacing and reconstruction projects in airports and highways. This material can be economically reused as a good quality paving material that conserves aggregate and asphalt, reduces transportation requirements, eliminates disposal problems, and lowers fuel consumption. Recycling of old asphalt concrete is not a new idea, but dates back to World War II. It is currently an important process in several countries that provides a useful source of aggregate for the construction industry from old asphalt concrete.

For example, in Canada asphalt concrete recycling has become a key component of the paving industry ${ }^{1}$. Methods and equipment for a range of cold and hot asphalt concrete recycling processes are well developed and widely used across Canada, particularly in highway projects and urban areas.

In Japan, asphalt concrete has become increasingly recycled as a major rehabilitation method since the Law on Recycling of Waste Materials took effect. Besides reducing costs and saving energy, the conservation of natural resources is even more important because Japan is relatively poor in natural aggregate reserves. For pavement rehabilitation projects at airports, all of the reclaimed materials must be used within the same project. A series of laboratory tests were conducted as a fundamental study to develop this strategy.

In this study, four types of base materials from reclaimed asphalt pavement (RAP) were evaluated: recycled granular material (RGM), recycled cement stabilized material (RCSM), recycled cement-emulsified asphalt stabilized material 
Table 1 Grain size analysis of aggregates

\begin{tabular}{|c|c|c|c|c|c|c|c|c|c|c|c|}
\hline \multicolumn{2}{|c|}{ Sieve $(\mathrm{mm})$} & 37.5 & 26.5 & 19.0 & 13.2 & 4.75 & 2.36 & 0.60 & 0.30 & 0.15 & 0.075 \\
\hline & & \multicolumn{10}{|c|}{ Passing percentage of weight (\%) } \\
\hline RAP & $20-13 \mathrm{~mm}$ & 100.0 & 100.0 & 94.4 & 10.0 & 0.8 & & & & & \\
\hline & $13-5 \mathrm{~mm}$ & & & 100.0 & 93.2 & 8.6 & 1.2 & 0.6 & 0.4 & 0.3 & 0.1 \\
\hline & $5-0 \mathrm{~mm}$ & & & & 100.0 & 95.2 & 51.4 & 10.4 & 3.9 & 1.1 & 0.4 \\
\hline $\begin{array}{c}\text { Crusher-run } \\
(\mathrm{C}-40)\end{array}$ & $40-0 \mathrm{~mm}$ & 100.0 & 90.8 & 75.8 & 60.1 & 19.9 & 15.8 & 9.4 & 7.6 & 6.1 & 5.0 \\
\hline
\end{tabular}

Table 2 Summary of properties of aggregates

\begin{tabular}{|c|c|c|c|c|c|c|}
\hline Type & \multicolumn{4}{|c|}{ RAP } & \multicolumn{2}{|c|}{ Crusher-run (C-40) } \\
\hline Grain size $(\mathrm{mm})$ & $20-13$ & $13-5$ & $5-2.36$ & $2.36-0$ & $40-2.36$ & $2.36-0$ \\
\hline Bulk specific gravity in saturated surface-dry & 2.553 & 2.531 & 2.407 & 2.300 & 2.665 & 2.472 \\
\hline Bulk density $\left(\mathrm{g} / \mathrm{cm}^{3}\right)$ & 2.533 & 2.507 & 2.358 & 2.261 & 2.644 & 2.370 \\
\hline Apparent density $\left(\mathrm{g} / \mathrm{cm}^{3}\right)$ & 2.583 & 2.567 & 2.479 & 2.352 & 2.701 & 2.637 \\
\hline Absorption (\%) & 0.75 & 0.94 & 2.06 & 1.71 & 0.79 & 4.27 \\
\hline Liquid limit (\%) & \multicolumn{4}{|c|}{$\mathrm{NP}$} & \multicolumn{2}{|c|}{20.4} \\
\hline Plastic limit (\%) & \multicolumn{4}{|c|}{ NP } & \multicolumn{2}{|c|}{17.3} \\
\hline Plastic index & \multicolumn{4}{|c|}{ NP } & \multicolumn{2}{|c|}{3.1} \\
\hline Loss percentage in washing test (\%) & & \multicolumn{3}{|c|}{0.4} & & \\
\hline Maximum specific gravity & 2.590 & 2.585 & \multicolumn{2}{|c|}{2.472} & & \\
\hline Maximum dry density $\left(\mathrm{g} / \mathrm{cm}^{3}\right)$ & & & & & \multicolumn{2}{|c|}{2.188} \\
\hline Optimum water content (\%) & & & & & \multicolumn{2}{|c|}{5.7} \\
\hline Modified CBR (\%) & & & & & \multicolumn{2}{|c|}{89} \\
\hline
\end{tabular}

Table 3 Properties of asphalt emulsion

\begin{tabular}{|c|c|c|}
\hline \multicolumn{2}{|r|}{ Testing items } & Result \\
\hline \multicolumn{2}{|c|}{ Engler viscosity $\left(25^{\circ} \mathrm{C}\right)$} & 7 \\
\hline \multicolumn{2}{|c|}{ Residue-on-sieving (1.18mm) (\%) } & 0 \\
\hline \multicolumn{2}{|c|}{ Cement mixing $(\%)$} & 0.2 \\
\hline \multicolumn{2}{|c|}{ Charge of particle } & Nonionic \\
\hline \multicolumn{2}{|c|}{ Residue by evaporation } & 60 \\
\hline \multirow{2}{*}{$\begin{array}{l}\text { Residue by } \\
\text { evaporation }\end{array}$} & Penetration $\left(25^{\circ} \mathrm{C}\right)$ & 195 \\
\hline & Solubility in toluene $(\%)$ & 99.87 \\
\hline \multicolumn{2}{|c|}{ Storage stability $(24 \mathrm{~h})(\%)$} & 0 \\
\hline \multicolumn{2}{|c|}{ Freezing stability $\left(-5^{\circ} \mathrm{C}\right)$} & - \\
\hline
\end{tabular}

Table 4 Properties of recycling agent

\begin{tabular}{|c|c|c|}
\hline \multicolumn{2}{|c|}{ Testing items } & Result \\
\hline \multicolumn{2}{|c|}{ Kinematic viscosity $\left(60^{\circ} \mathrm{C}\right)\left(\mathrm{mm}^{2} / \mathrm{s}\right)$} & 244.9 \\
\hline \multicolumn{2}{|c|}{ Flash point $(\mathrm{COC})\left({ }^{\circ} \mathrm{C}\right)$} & 224 \\
\hline \multicolumn{2}{|c|}{ Viscosity ratio after thin film oven $\left(60^{\circ} \mathrm{C}\right)$} & 1.33 \\
\hline \multicolumn{2}{|c|}{ Loss on thin film oven test (\%) } & -1.84 \\
\hline \multicolumn{2}{|c|}{ Specific gravity } & 1.0329 \\
\hline \multirow{5}{*}{$\begin{array}{c}\text { Component analyses } \\
\text { (mass \%) }\end{array}$} & Asphaltene & 0.0 \\
\hline & Saturates & 41.3 \\
\hline & Aromatics & 47.5 \\
\hline & Resin & 6.6 \\
\hline & Recovery ratio & 95.4 \\
\hline
\end{tabular}

(RCESM) and recycled hot-asphalt stabilized material (RHSM). The primary objectives of this study were as follows.

1) Evaluate the performance of recycled base materials from Tokyo International Airport;

2) Determine the procedure for preparing these base materials to meet the specification.

\section{PERFORMANCES OF MATERIALS}

The following materials were used in this study: reclaimed asphalt pavement (RAP) from Tokyo International Airport, crusher-run C-40, Portland cement, asphalt emulsion, virgin asphalt (Straight asphalt 60/80) and recycling agent. Table 1 and

Table 2 give the grain size analysis and the key 
Table 5 Result of asphalt extraction test

\begin{tabular}{|c|c|c|c|c|c|c|c|c|c|c|c|c|}
\hline \multirow{2}{*}{ Sieve $(\mathrm{mm})$} & 37.5 & 26.5 & 19.0 & 13.2 & 4.75 & 2.36 & 0.60 & 0.30 & 0.15 & 0.075 & $\begin{array}{c}\text { Asphalt content } \\
(\%)\end{array}$ \\
\cline { 2 - 15 } & \multicolumn{10}{|c|}{ Passing percentage of weight (\%) } \\
\hline \multirow{3}{*}{ RAP } & $20-13 \mathrm{~mm}$ & 100.0 & 100.0 & 98.9 & 55.4 & 27.1 & 20.7 & 13.5 & 10.3 & 8.3 & 4.9 & 2.3 \\
\cline { 2 - 14 } & $13-5 \mathrm{~mm}$ & & & 100.0 & 94.9 & 31.4 & 19.5 & 13.3 & 10.2 & 7.9 & 4.8 & 2.6 \\
\cline { 2 - 13 } & $5-0 \mathrm{~mm}$ & & & & 100.0 & 98.1 & 65.0 & 35.4 & 26.1 & 18.0 & 11.9 & 6.2 \\
\cline { 2 - 12 } & $20-0 \mathrm{~mm}$ & 100.0 & 100.0 & 98.6 & 82.6 & 52.4 & 37.7 & 21.9 & 16.2 & 12.2 & 7.7 & 4.4 \\
\hline
\end{tabular}

Table 7 Combined gradations of RGM

\begin{tabular}{|c|c|c|c|c|c|c|c|c|c|c|c|}
\hline \multirow{2}{*}{\multicolumn{2}{|c|}{ Sieve (mm) }} & 37.5 & 26.5 & 19.0 & 13.2 & 4.75 & 2.36 & 0.60 & 0.30 & 0.15 & 0.075 \\
\hline & & \multicolumn{10}{|c|}{ Passing percentage of weight (\%) } \\
\hline \multirow{5}{*}{$\begin{array}{l}\text { Ratio of } \\
\text { RAP (\%) }\end{array}$} & 100 & 100.0 & 100.0 & 98.8 & 77.7 & 40.2 & 20.4 & 4.2 & 1.7 & 0.5 & 0.2 \\
\hline & 75 & 100.0 & 97.7 & 93.1 & 73.3 & 35.2 & 19.3 & 5.6 & 3.2 & 1.9 & 1.5 \\
\hline & 50 & 100.0 & 95.4 & 87.3 & 69.0 & 30.1 & 18.1 & 6.8 & 4.7 & 3.4 & 2.6 \\
\hline & 25 & 100.0 & 93.1 & 81.6 & 64.5 & 25.0 & 17.0 & 8.2 & 6.1 & 4.7 & 3.9 \\
\hline & 0 & 100.0 & 90.8 & 75.8 & 60.1 & 19.9 & 15.8 & 9.4 & 7.6 & 6.1 & 5.0 \\
\hline
\end{tabular}

Table 8 Results of compaction test and modified CBR test for RGM

\begin{tabular}{|c|c|c|c|c|c|}
\hline \multirow{2}{*}{ Items } & \multicolumn{5}{|c|}{ Ratio of RAP $(\%)$} \\
\cline { 2 - 6 } & 0 & 25 & 50 & 75 & 100 \\
\hline Maximum dry density $\left(\mathrm{g} / \mathrm{cm}^{3}\right)$ & 2.188 & 2.121 & 2.090 & 2.010 & 1.943 \\
\hline Optimum water content $(\%)$ & 5.7 & 5.7 & 6.2 & 7.0 & 5.2 \\
\hline Modified CBR $(\%)$ & 89.0 & 33.0 & 13.0 & 6.6 & 4.2 \\
\hline
\end{tabular}

Table 6 Gradation ratio of RAP

\begin{tabular}{|l|l|l|l|}
\hline Grain size (mm) & $20-13$ & $13-5$ & $5-0$ \\
\hline
\end{tabular}

\begin{tabular}{|l|l|l|l|}
\hline Weight ratio $(\%)$ & 21.8 & 39.5 & 38.7 \\
\hline
\end{tabular}

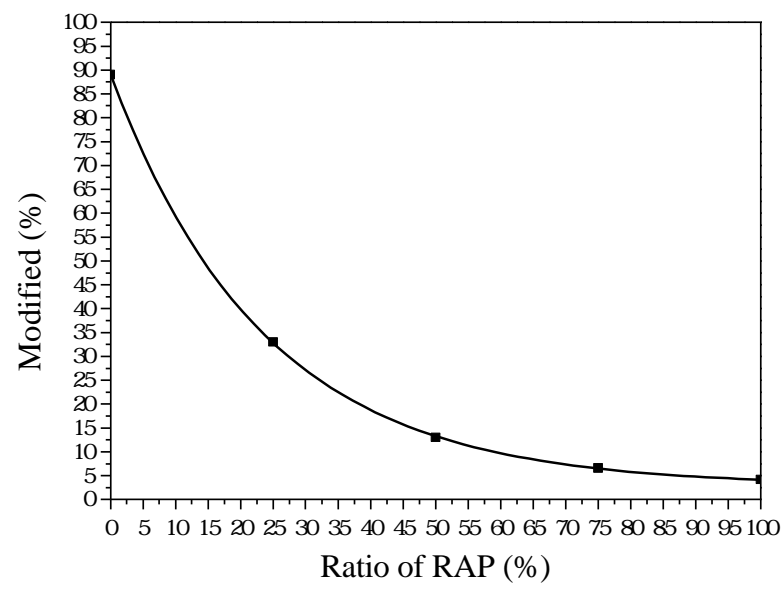

Fig.1 Modified CBR test for RGM

performance characteristics of the aggregates, respectively. Table 3 and Table 4 also show the properties of asphalt emulsion and recycling agent, respectively.

The asphalt extraction test (Soxhlet method) ${ }^{2)}$ was used to evaluate the performance of the reclaimed asphalt pavement. Table 5 shows the results. The penetration of the recycled asphalt is 23
$(1 / 100 \mathrm{~cm})$.

\section{COMPOSITION DESIGNS AND PROPERTIES OF BASE MATERIALS}

In this study, the properties of the four types of materials were investigated.

\section{(1) Recycled granular material (RGM) \\ a) Composition}

The simplest use of old asphalt concrete is uniform blending, at a plant or in-place, of suitably processed, reclaimed asphalt pavement (RAP) with conventional granular material for base course or subbase applications. The recycled granular material in this study was composed of RAP or/and crusher-run C-40. The RAP is classified into three different grain sizes with gradation ratios given in Table 6. For recycled granular material (RGM), five combinations of RAP and C- 40 were tested at $40^{\circ} \mathrm{C}^{3)}$, with RAP ratios of $100 \%, 75 \%, 50 \%, 25 \%$ and $0 \%$.

Table 7 gives their combined gradations. To obtain adequate RGM compaction, care must be taken to avoid segregation. 
Table 9 Modified CBR targets

\begin{tabular}{|c|c|c|}
\hline Type & Modified CBR (\%) & Ratio of RAP \\
\hline \multirow{2}{*}{ Base course } & 80 & 3 \\
\cline { 2 - 3 } & 45 & 18 \\
\hline \multirow{2}{*}{ Subbase } & 30 & 28 \\
\cline { 2 - 3 } & 20 & 37 \\
\hline
\end{tabular}

Table 10 Compaction test for RCSM

\begin{tabular}{|c|c|c|c|c|c|c|c|c|}
\hline \multirow{2}{*}{ Type } & \multicolumn{9}{|c|}{ Ratio of RAP (\%) } \\
\cline { 2 - 9 } & \multicolumn{2}{|c|}{25} & \multicolumn{3}{c|}{50} & \multicolumn{2}{c|}{75} & \multicolumn{2}{c|}{100} \\
\hline Cement content $(\%)$ & 4 & 8 & 4 & 8 & 4 & 8 & 4 & 8 \\
\hline Maximum dry density $\left(\mathrm{g} / \mathrm{cm}^{3}\right)$ & 2.055 & 2.135 & 1.966 & 2.072 & 1.872 & 1.968 & 1.772 & 1.871 \\
\hline Optimum water content $(\%)$ & 5.9 & 7.9 & 6.0 & 7.7 & 6.7 & 7.7 & 5.5 & 6.1 \\
\hline
\end{tabular}

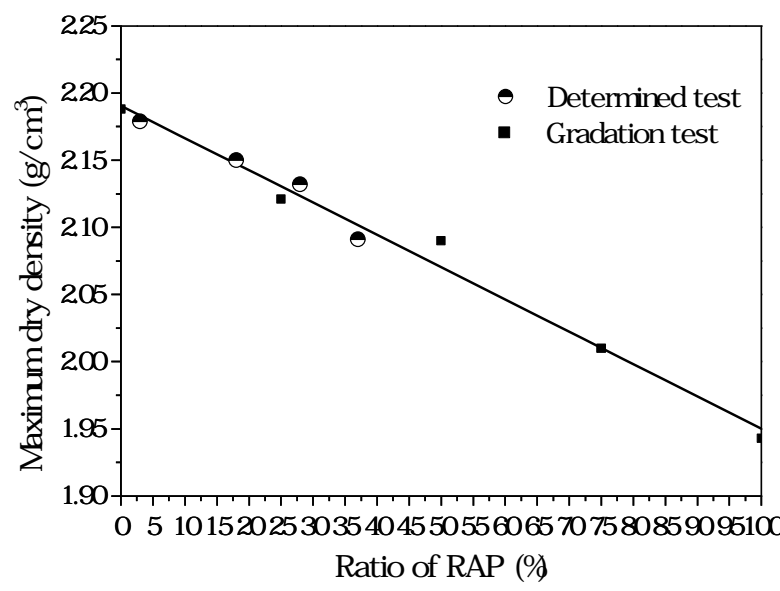

Fig.2 Maximum dry density for RGM

The compaction and modified CBR tests ${ }^{2)}$ were employed for these gradations to determine the optimum ratio of RAP in RGM. Table 8 summarizes the results.

Fig.1 shows the relationship between the modified CBR and the ratio of RAP. The CBR of RGM decreases significantly for RAP ratios greater than about $20 \%$. Based on the current specification ${ }^{4)}$, the modified CBR should be over $80 \%$ for the base course and over $30 \%$ for the subbase of asphalt pavements, and over $45 \%$ and $20 \%$ for the base course and subbase, respectively, for concrete pavements. Consequently, when a target modified CBR is specified, the corresponding ratio of RAP can be determined from the figure (seen in Table 9).

The compaction test was also used to verify the compositions (Table 10). Figs. 2 and 3 show the relationship of the ratio of RAP to the maximum dry density and optimum water content, respectively. These figures confirm the ratios of RAP listed in

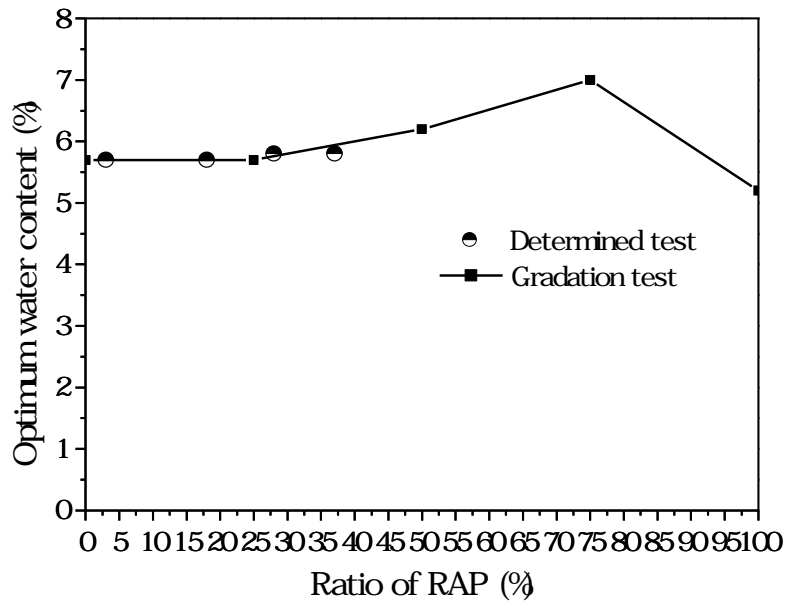

Fig.3 Optimum water content for RGM

Table 9. Unfortunately, the use of RAP in RGM does not have a major advantage for reclaimed asphalt concrete.

\section{b) Properties}

Based on the ratios of RAP in Table 9, the modified CBR test and the CBR test were conducted to evaluate the performance of RGM under different temperatures and curing methods. Fig.4 shows the effect of temperature on the modified CBR. Obviously, the modified CBR is higher at lower temperatures. Moreover, the modified CBR increases with decreasing ratio of RAP. This phenomenon shows that RGM is sensitive to the temperature. Therefore, if the material is used in hot locations, the ratio of RAP should be strictly controlled.

Fig.5 gives the effects of the temperature and curing method on CBR. The following findings were obtained.

(a) For a constant temperature, the CBR of RGM cured in air is generally greater than that cured in 


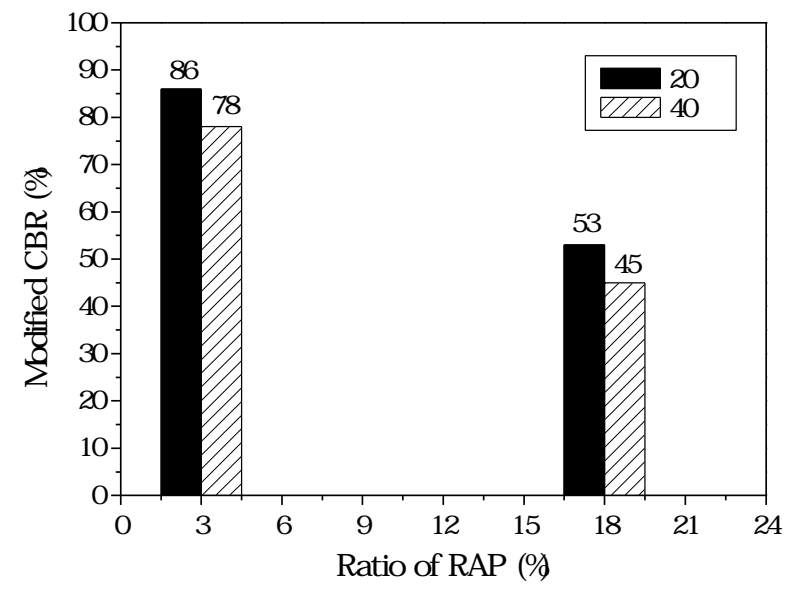

(a) Base course

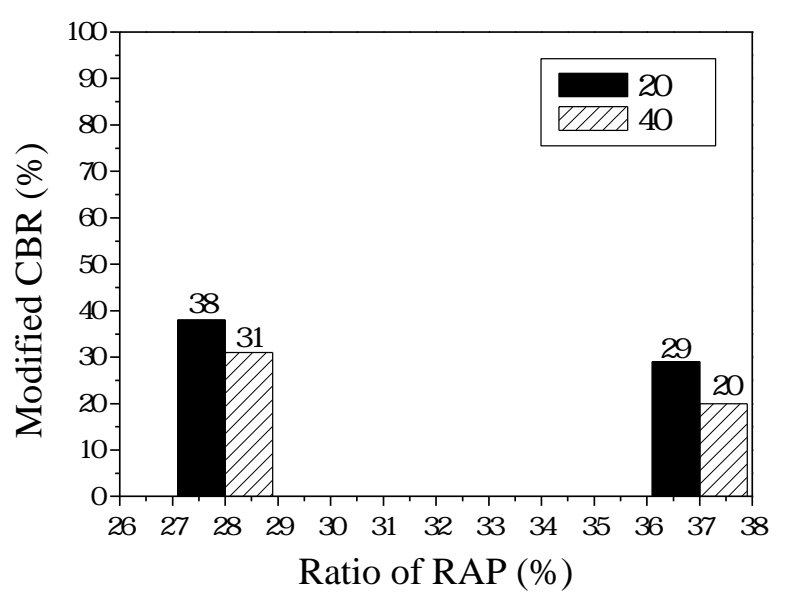

(b) Subbase

Fig.4 Effect of temperature on modified CBR for RGM

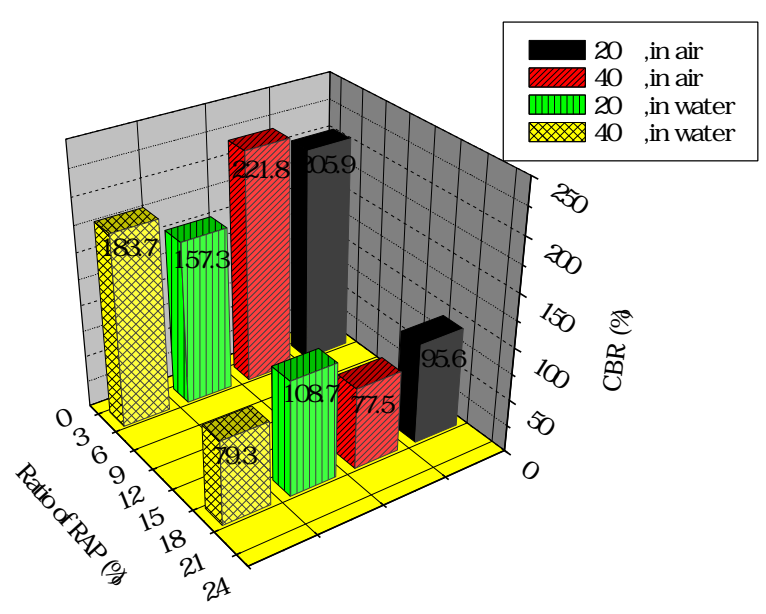

(a) Base course

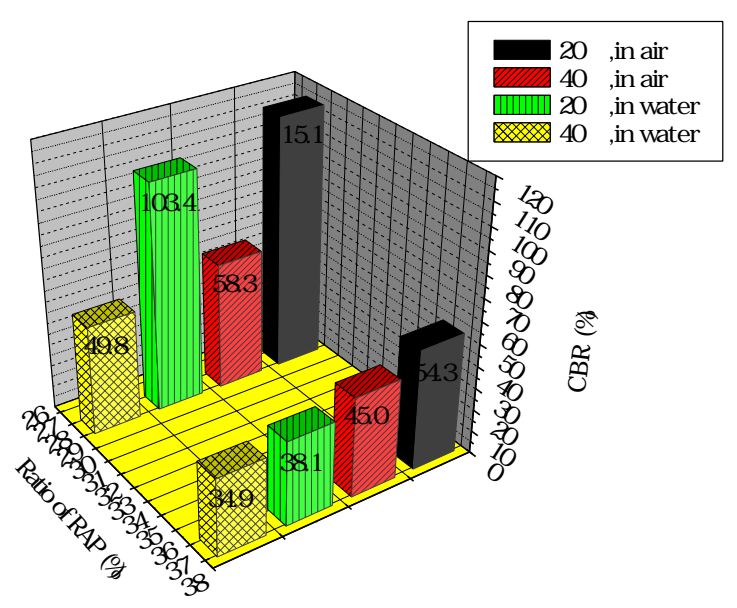

(b) Subbase

Fig.5 Effect of temperature and curing method on CBR for RGM

water. Therefore, if RGM is used for a base course, a good drainage system is necessary.

(b) For the same curing method, the CBR of RGM for a subbase at $20^{\circ} \mathrm{C}$ is greater than that at $40^{\circ} \mathrm{C}$; whereas for a base course with a RAP ratio of $3 \%$, the conclusion is opposite. The case again shows that RGM with a large ratio of RAP is very sensitive to temperature.

\section{(2) Recycled cement stabilized material (RCSM)}

\section{a) Composition}

The aggregates used were the same as those of the RGM. However, the portion with a grain size of 26.5 and larger was removed. Four ratios of RAP $(100 \%, 75 \%, 50 \%$ and $25 \%)$ were evaluated with compaction tests and unconfined compression tests ${ }^{2)}$.
The cement content in the samples for the compaction test was $4 \%$ and $8 \%$, while contents of $2 \%, 4 \%, 6 \%, 8 \%$ and $10 \%$ were used for the unconfined compression test. Table 10 and Table 11 give the results for the compaction and unconfined compression tests, respectively. Regardless of the RAP ratio, the cement content significantly effects the maximum dry density and optimum water content of RCSM. Fig.6 indicates the relationship between the unconfined compression strength and the cement content. According to the relevant specifications for airports $^{4)}$, the unconfined compression strength of RCSM should be not less than $3 \mathrm{~N} / \mathrm{mm}^{2}$ for the base course, nor less than $2 \mathrm{~N} / \mathrm{mm}^{2}$ for the subbase. Cement contents that satisfy the requirements for various RAP ratios can be obtained from Fig.6.

Unconfined compression tests were conducted to 
Table 11 Unconfined compression test result for RCSM

\begin{tabular}{|c|c|c|c|c|c|}
\hline \multicolumn{2}{|c|}{} & \multicolumn{4}{|c|}{ Ratio of RAP $(\%)$} \\
\hline Cement content $(\%)$ & Type & 25 & 50 & 75 & 100 \\
\hline \multirow{2}{*}{2} & Strength $\left(\mathrm{N} / \mathrm{mm}^{2}\right)$ & 1.32 & 0.57 & 0.31 & 0.25 \\
\cline { 2 - 6 } & Dry density $\left(\mathrm{g} / \mathrm{cm}^{3}\right)$ & 2.03 & 1.891 & 1.819 & 1.738 \\
\hline \multirow{2}{*}{4} & Strength $\left(\mathrm{N} / \mathrm{mm}^{2}\right)$ & 3.23 & 1.97 & 0.94 & 0.64 \\
\cline { 2 - 6 } & Dry density $\left(\mathrm{g} / \mathrm{cm}^{3}\right)$ & 2.059 & 1.969 & 1.855 & 1.774 \\
\hline \multirow{2}{*}{6} & Strength $\left(\mathrm{N} / \mathrm{mm}^{2}\right)$ & 5.16 & 3.1 & 1.77 & 1.39 \\
\cline { 2 - 6 } & Dry density $\left(\mathrm{g} / \mathrm{cm}^{3}\right)$ & 2.106 & 2.01 & 1.938 & 1.826 \\
\hline \multirow{2}{*}{8} & Strength $\left(\mathrm{N} / \mathrm{mm}^{2}\right)$ & 6.31 & 4.24 & 2.67 & 1.84 \\
\cline { 2 - 6 } & Dry density $\left(\mathrm{g} / \mathrm{cm}^{3}\right)$ & 2.142 & 2.073 & 1.965 & 1.870 \\
\hline \multirow{2}{*}{10} & Strength $\left(\mathrm{N} / \mathrm{mm}^{2}\right)$ & 8.97 & 6.36 & 3.62 & 2.34 \\
\cline { 2 - 6 } & Dry density $\left(\mathrm{g} / \mathrm{cm}^{3}\right)$ & 2.178 & 2.139 & 1.985 & 1.892 \\
\hline
\end{tabular}

Table 12 Determining cement content

\begin{tabular}{|c|c|c|}
\hline \multirow{2}{*}{ Ratio of RAP $(\%)$} & \multicolumn{2}{|c|}{ Cement content (\%) } \\
\cline { 2 - 3 } & Target strength: 3N/mm $\mathrm{mm}^{2}$ (base course) & Target strength: $2 \mathrm{~N} / \mathrm{mm}^{2}$ (subbase) \\
\hline 25 & 3.9 & 2.8 \\
\hline 50 & 5.7 & 4.2 \\
\hline 75 & 8.8 & 6.4 \\
\hline 100 & 12.4 & 8.7 \\
\hline
\end{tabular}

Table 13 Verification test result of RCSM

\begin{tabular}{|c|c|c|c|c|c|c|c|c|}
\hline Target strength $\left(\mathrm{N} / \mathrm{mm}^{2}\right)$ & \multicolumn{4}{|c|}{3 (base course) } & \multicolumn{4}{c|}{2 (subbase) } \\
\hline Ratio of reclaimed asphalt pavement (\%) & 100 & 75 & 50 & 25 & 100 & 75 & 50 & 25 \\
\hline Cement content (\%) & 12.4 & 8.8 & 5.7 & 3.9 & 8.7 & 6.4 & 4.2 & 2.8 \\
\hline Actual strength $\left(\mathrm{N} / \mathrm{mm}^{2}\right)$ & 3.03 & 3.19 & 2.97 & 2.76 & 1.74 & 2.02 & 2.10 & 2.01 \\
\hline Dry density $\left(\mathrm{g} / \mathrm{cm}^{3}\right)$ & 1.888 & 2.015 & 2.048 & 2.062 & 1.873 & 1.955 & 2.012 & 2.046 \\
\hline
\end{tabular}

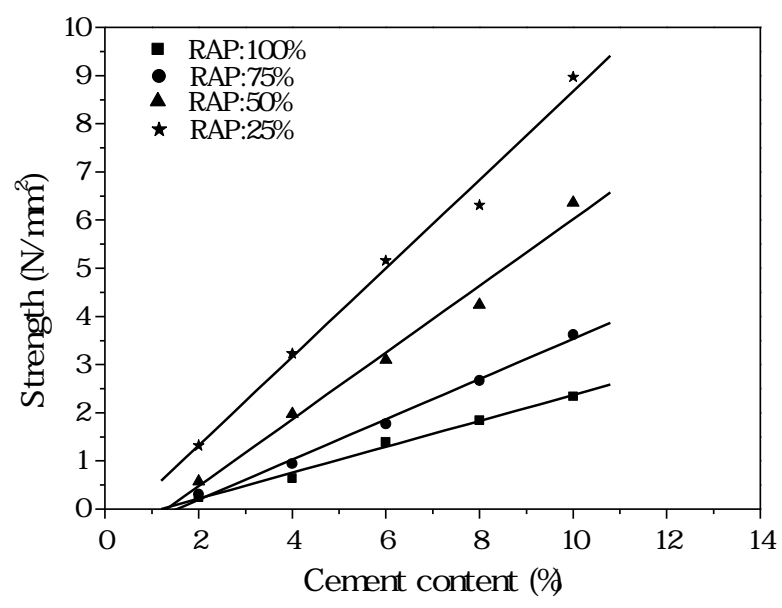

Fig.6 Strength and cement content for RCSM

verify the specified compositions. The results shown in Table 13 indicate that the cement contents in Table 12 can satisfy the strength requirement for a base course in an airport. The gradation of RCSM was thus determined.

\section{b) Properties}

This study incorporated the unconfined compression test, the freeze-thaw test and the dry-wet repeated test.
Table 14 gives the test conditions for the unconfined compression test. Table 15 shows the test results. The temperature, period and method of curing have a great effect on the properties of RCSM. When other conditions are same, the strength at $20^{\circ} \mathrm{C}$ is higher than that at $40^{\circ} \mathrm{C}$, showing that RCSM is also sensitive to temperature. The strength of RCSM increases with the curing period, which is similar to its effect on cement concrete. Although the strength when cured in water is less than that in air, the properties of RCSM can satisfy the specified requirement with a suitable cement content.

The freeze-thaw test and the dry-wet repeated test were conducted to evaluate the durability of RCSM. The results, shown in Table $\mathbf{1 6}$ and Table 17, indicate that RCSM has good durability, so it can be used in areas with severe climate conditions.

\section{(3) Recycled cement-emulsified asphalt stabilized material (RCESM) \\ a) Composition}

The aggregates and other components were the same as those used in the recycled cement stabilized 
Table 14 Test conditions for RCSM

\begin{tabular}{|c|c|c|c|c|c|c|c|c|}
\hline Curing period (days) & \multicolumn{2}{|c|}{7} & \multicolumn{2}{|c|}{28} & \multicolumn{4}{|c|}{91} \\
\hline Curing method & \multicolumn{2}{|c|}{ In air } & \multicolumn{2}{|c|}{ In air } & \multicolumn{2}{|c|}{ In air } & \multicolumn{2}{|c|}{$28 \mathrm{~d}$ in air, $63 \mathrm{~d}$ in water } \\
\hline Curing temp. $\left({ }^{\circ} \mathrm{C}\right)$ & 20 & 40 & 20 & 40 & 20 & 40 & 20 & 40 \\
\hline
\end{tabular}

Table 15 Test results for RCSM

a) Base course

\begin{tabular}{|c|c|c|c|c|c|c|c|c|c|}
\hline \multirow{2}{*}{$\begin{array}{c}\text { Curing period } \\
\text { and method }\end{array}$} & Test temp. $\left({ }^{\circ} \mathrm{C}\right)$ & \multicolumn{4}{|c|}{20} & \multicolumn{4}{c|}{40} \\
\cline { 2 - 10 } & Ratio of RAP $(\%)$ & 25 & 50 & 75 & 100 & 25 & 50 & 75 & 100 \\
\cline { 2 - 10 } & Cement content $(\%)$ & 3.9 & 5.7 & 8.8 & 12.4 & 3.9 & 5.7 & 8.8 & 12.4 \\
\hline \multirow{2}{*}{$7 \mathrm{~d}$, in air } & Strength $\left(\mathrm{N} / \mathrm{mm}^{2}\right)$ & 2.91 & 3.46 & 3.04 & 3.67 & 2.57 & 2.68 & 2.67 & 2.64 \\
\cline { 2 - 11 } & Dry density $\left(\mathrm{g} / \mathrm{cm}^{3}\right)$ & 2.057 & 2.037 & 2.026 & 1.970 & 2.052 & 2.045 & 2.025 & 1.976 \\
\hline \multirow{2}{*}{ 28d, in air } & Strength $\left(\mathrm{N} / \mathrm{mm}^{2}\right)$ & 3.35 & 3.51 & 3.85 & 4.38 & 4.04 & 3.14 & 3.33 & 3.29 \\
\cline { 2 - 11 } & Dry density $\left(\mathrm{g} / \mathrm{cm}^{3}\right)$ & 2.071 & 2.027 & 2.010 & 1.986 & 2.077 & 2.021 & 2.009 & 1.997 \\
\hline \multirow{2}{*}{ 91d, in air } & Strength $\left(\mathrm{N} / \mathrm{mm}^{2}\right)$ & 4.78 & 4.92 & 5.66 & 5.43 & 4.09 & 3.98 & 3.58 & 4.33 \\
\cline { 2 - 10 } & Dry density $\left(\mathrm{g} / \mathrm{cm}^{3}\right)$ & 2.082 & 2.033 & 2.022 & 1.997 & 2.080 & 2.034 & 2.019 & 2.000 \\
\hline \multirow{2}{*}{ 91d, in water } & Strength $\left(\mathrm{N} / \mathrm{mm}^{2}\right)$ & 3.54 & 3.81 & 4.08 & 5.31 & 2.79 & 2.99 & 3.04 & 3.06 \\
\cline { 2 - 10 } & Dry density $\left(\mathrm{g} / \mathrm{cm}^{3}\right)$ & 2.088 & 2.030 & 2.009 & 1.960 & 2.078 & 2.033 & 2.011 & 1.958 \\
\hline
\end{tabular}

b) Subbase

\begin{tabular}{|c|c|c|c|c|c|c|c|c|c|}
\hline \multirow{2}{*}{$\begin{array}{c}\text { Curing period } \\
\text { and method }\end{array}$} & Test temp. $\left({ }^{\circ} \mathrm{C}\right)$ & \multicolumn{4}{|c|}{20} & \multicolumn{4}{c|}{40} \\
\cline { 2 - 10 } & Ratio of RAP $(\%)$ & 25 & 50 & 75 & 100 & 25 & 50 & 75 & 100 \\
\cline { 2 - 10 } & Cement content $(\%)$ & 2.8 & 4.2 & 6.4 & 8.7 & 2.8 & 4.2 & 6.4 & 8.7 \\
\hline \multirow{2}{*}{$7 \mathrm{~d}$, in air } & Strength $\left(\mathrm{N} / \mathrm{mm}^{2}\right)$ & 2.26 & 2.04 & 1.87 & 2.22 & 1.90 & 1.90 & 1.58 & 1.45 \\
\cline { 2 - 10 } & Dry density $\left(\mathrm{g} / \mathrm{cm}^{3}\right)$ & 2.040 & 1.998 & 1.924 & 1.900 & 2.030 & 2.002 & 1.927 & 1.912 \\
\hline \multirow{2}{*}{$28 \mathrm{~d}$, in air } & Strength $\left(\mathrm{N} / \mathrm{mm}^{2}\right)$ & 2.73 & 2.34 & 2.23 & 2.09 & 2.99 & 2.05 & 1.81 & 1.61 \\
\cline { 2 - 10 } & Dry density $\left(\mathrm{g} / \mathrm{cm}^{3}\right)$ & 2.046 & 1.974 & 1.946 & 1.886 & 2.044 & 1.983 & 1.946 & 1.877 \\
\hline \multirow{2}{*}{ 91d, in air } & Strength $\left(\mathrm{N} / \mathrm{mm}^{2}\right)$ & 3.39 & 2.79 & 3.11 & 3.12 & 2.93 & 2.43 & 2.12 & 1.97 \\
\cline { 2 - 10 } & Dry density $\left(\mathrm{g} / \mathrm{cm}^{3}\right)$ & 2.053 & 1.986 & 1.939 & 1.905 & 2.050 & 1.989 & 1.942 & 1.916 \\
\hline \multirow{2}{*}{ 91d, in water } & Strength $\left(\mathrm{N} / \mathrm{mm}^{2}\right)$ & 2.44 & 2.48 & 2.59 & 2.50 & 2.31 & 2.02 & 1.86 & 1.69 \\
\cline { 2 - 10 } & Dry density $\left(\mathrm{g} / \mathrm{cm}^{3}\right)$ & 2.058 & 1.990 & 1.949 & 1.890 & 2.066 & 1.999 & 1.941 & 1.894 \\
\hline
\end{tabular}

Table 16 Freeze-thaw test results for RCSM

\begin{tabular}{|c|c|c|c|c|c|c|c|c|c|}
\hline Type & \multicolumn{4}{|c|}{ Base course } & \multicolumn{4}{c|}{ Subbase } & Specified value \\
\hline Ratio of RAP (\%) & 25 & 50 & 75 & 100 & 25 & 50 & 75 & 100 & \\
\hline Cement content (\%) & 3.9 & 5.7 & 8.8 & 12.4 & 2.8 & 4.2 & 6.4 & 8.7 & \\
\hline Lost weight (g) & 44.0 & 16.8 & 13.2 & 11.5 & 54.0 & 21.6 & 16.8 & 16.9 & \\
\hline Lost ratio (\%) & 1.21 & -0.15 & 0.80 & -0.11 & 0.84 & 0.63 & 1.22 & 0.37 & Below 14 \\
\hline Maximum volume variation (\%) & 0.40 & 0.35 & 0.35 & 0.28 & 0.36 & 0.48 & 0.28 & 0.59 & Below 2 \\
\hline
\end{tabular}

Table 17 Dry-wet repeated test results for RCSM

\begin{tabular}{|c|c|c|c|c|c|c|c|c|c|}
\hline Type & \multicolumn{4}{|c|}{ Base course } & \multicolumn{4}{c|}{ Subbase } & Specified value \\
\hline Ratio of RAP (\%) & 25 & 50 & 75 & 100 & 25 & 50 & 75 & 100 & \\
\hline Cement content (\%) & 3.9 & 5.7 & 8.8 & 12.4 & 2.8 & 4.2 & 6.4 & 8.7 & \\
\hline Lost weight (g) & 28.7 & 9.4 & 6.0 & 7.1 & 49.7 & 19.1 & 8.7 & 8.7 & \\
\hline Lost ratio (\%) & 1.19 & 0.50 & 1.47 & 0.24 & 1.80 & 0.59 & 0.28 & 0.36 & Below 14 \\
\hline Maximum volume variation (\%) & 0.60 & 0.28 & 0.48 & 0.31 & 0.56 & 0.48 & 0.40 & 0.35 & Below 2 \\
\hline
\end{tabular}

material. Two RAP contents were evaluated: $100 \%$ and $75 \%$. The emulsion content was determined based on the Technical Guidelines for Recycled Base Course Method ${ }^{3)}$. Table 18 and Table 19 give the results of the compaction and unconfined compression tests, respectively. The cement content has a clear effect on RCESM. Fig.7 easily provides the cement content for a given unconfined compression strength under different ratios of RAP. Consequently, Table 20 shows the determined gradation of RCESM that satisfies the base requirement.

\section{b) Properties}

The unconfined compression test was conducted to investigate the effect of temperature and curing method on the properties of RCESM. Table 21 
Table 18 Compaction test for RCESM

\begin{tabular}{|c|c|c|c|}
\hline \multirow{2}{*}{ Type } & \multirow{2}{*}{ Cement content $(\%)$} & \multicolumn{2}{|c|}{ Ratio of RAP $(\%)$} \\
\cline { 3 - 4 } & & 75 & 100 \\
\hline \multirow{2}{*}{ Maximum dry density $\left(\mathrm{g} / \mathrm{cm}^{3}\right)$} & 4 & 1.910 & 1.835 \\
\cline { 2 - 4 } & 8 & 2.000 & 1.892 \\
\hline \multirow{2}{*}{ Optimum water content $(\%)$} & 4 & 3.8 & 3.5 \\
\cline { 2 - 4 } & 8 & 5.3 & 4.3 \\
\hline
\end{tabular}

Table 19 Unconfined compression test for RCESM

\begin{tabular}{|c|c|c|c|c|c|c|}
\hline \multicolumn{2}{|c|}{} & \multicolumn{5}{|c|}{ Cement content $(\%)$} \\
\hline Ratio of RAP $(\%)$ & Type & 2 & 4 & 6 & 8 & 10 \\
\hline \multirow{2}{*}{75} & Strength $\left(\mathrm{N} / \mathrm{mm}^{2}\right)$ & 0.31 & 0.94 & 1.77 & 2.67 & 3.62 \\
\cline { 2 - 7 } & Dry density $\left(\mathrm{g} / \mathrm{cm}^{3}\right)$ & 1.819 & 1.855 & 1.938 & 1.965 & 1.985 \\
\hline \multirow{2}{*}{100} & Strength $\left(\mathrm{N} / \mathrm{mm}^{2}\right)$ & 0.25 & 0.64 & 1.39 & 1.84 & 2.34 \\
\cline { 2 - 7 } & Dry density $\left(\mathrm{g} / \mathrm{cm}^{3}\right)$ & 1.738 & 1.774 & 1.826 & 1.870 & 1.892 \\
\hline
\end{tabular}

Table 20 Determined gradation for RCESM

\begin{tabular}{|c|c|c|c|c|}
\hline Target strength $\left(\mathrm{N} / \mathrm{mm}^{2}\right)$ & \multicolumn{2}{|c|}{3 (base course) } & \multicolumn{2}{c|}{2 (subbase) } \\
\hline Ratio of RAP $(\%)$ & 75 & 100 & 75 & 100 \\
\hline Cement content $(\%)$ & 8.1 & 11.1 & 6.4 & 8.6 \\
\hline Measured strength $\left(\mathrm{N} / \mathrm{mm}^{2}\right)$ & 2.89 & 2.98 & 1.88 & 1.73 \\
\hline Dry density $\left(\mathrm{g} / \mathrm{cm}^{3}\right)$ & 1.991 & 1.946 & 1.926 & 1.867 \\
\hline
\end{tabular}

Table 21 Properties of RCESM

\begin{tabular}{|c|c|c|c|c|c|c|c|c|c|}
\hline \multirow{4}{*}{ Curing } & Target strength & \multicolumn{4}{|c|}{$3 \mathrm{~N} / \mathrm{mm}^{2}$ (base course) } & \multicolumn{4}{|c|}{$2 \mathrm{~N} / \mathrm{mm}^{2}$ (subbase) } \\
\hline & Test temperature & \multicolumn{2}{|c|}{$20^{\circ} \mathrm{C}$} & \multicolumn{2}{|c|}{$40^{\circ} \mathrm{C}$} & \multicolumn{2}{|c|}{$20^{\circ} \mathrm{C}$} & \multicolumn{2}{|c|}{$40^{\circ} \mathrm{C}$} \\
\hline & Ratio of RAP & $75 \%$ & $100 \%$ & $75 \%$ & $100 \%$ & $75 \%$ & $100 \%$ & $75 \%$ & $100 \%$ \\
\hline & Cement content $(\%)$ & 8.1 & 11.1 & 8.1 & 11.1 & 6.4 & 8.6 & 6.4 & 8.6 \\
\hline \multirow[t]{2}{*}{$91 \mathrm{~d}$ in air } & $\begin{array}{l}\text { Measured strength } \\
\left(\mathrm{N} / \mathrm{mm}^{2}\right)\end{array}$ & 4.85 & 4.42 & 3.29 & 2.43 & 2.91 & 2.57 & 2.08 & 1.52 \\
\hline & Dry density $\left(\mathrm{g} / \mathrm{cm}^{3}\right)$ & 2.014 & 1.947 & 2.026 & 1.946 & 1.960 & 1.897 & 1.974 & 1.910 \\
\hline \multirow{2}{*}{$23 \mathrm{~d}$ in air, $63 \mathrm{~d}$ in water } & $\begin{array}{l}\text { Measured strength } \\
\left(\mathrm{N} / \mathrm{mm}^{2}\right)\end{array}$ & 4.18 & 3.14 & 2.85 & 1.89 & 2.45 & 1.65 & 1.66 & 1.11 \\
\hline & Dry density $\left(\mathrm{g} / \mathrm{cm}^{3}\right)$ & 2.026 & 1.952 & 2.028 & 1.941 & 1.974 & 1.908 & 1.977 & 1.903 \\
\hline
\end{tabular}

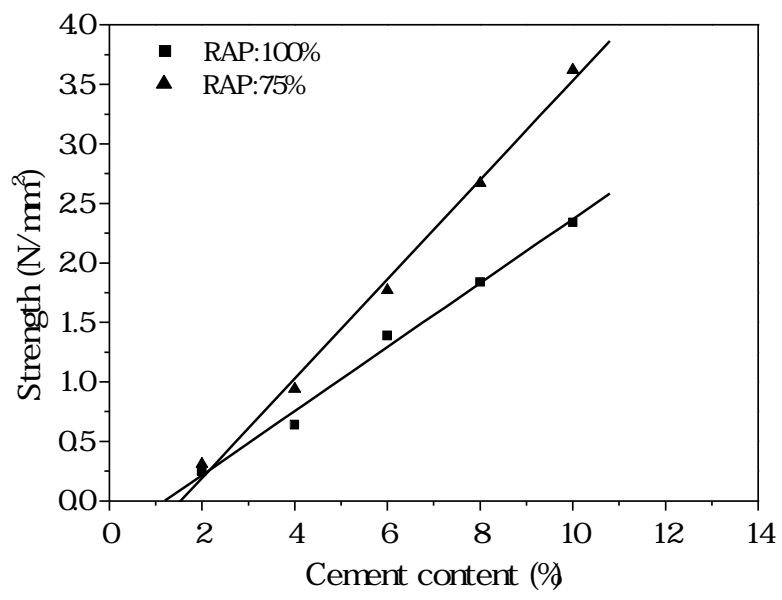

Fig.7 Strength and cement content (for RCESM)

shows the results, which suggest the following conclusions: (a) Strength decreases with increasing temperature, which indicates that RCESM is also sensitive to the temperature. (b) The curing method has a significant influence on the properties. Curing in air is better than in water. (c) The required strength may not be achieved if the temperature is high and the ratio of RAP is large.

\section{(4) Recycled hot-asphalt stabilized material (RHASM)}

Hot-mix recycling of asphalt concrete is used increasingly as a primary rehabilitation method by pavement agencies throughout Japan. However, it is a complex process that will be researched in another special study. Therefore, in this study, only the RHASM composition with a $100 \%$ RAP ratio was analyzed.

Table 22 gives the combined gradation of RHASM, which is within the standard range of grain size. As discussed previously, penetration of the recycled asphalt is $23(1 / 100 \mathrm{~cm})$, which does not satisfy the target design penetration of $70(1 / 100 \mathrm{~cm})$. 
Table 22 Combined gradation of RHASM

\begin{tabular}{|c|c|c|c|c|c|c|c|c|c|}
\hline Sieve (mm) & 19.0 & 13.2 & 4.75 & 2.36 & 0.60 & 0.30 & 0.15 & 0.075 & Asphalt content (\%) \\
\hline $\begin{array}{c}\text { Passing percentage } \\
\text { of weight (\%) }\end{array}$ & 99.8 & 89.1 & 56.3 & 37.1 & 21.7 & 16.2 & 11.7 & 7.5 & 4.29 \\
\hline Gradation range (\%) & $50-100$ & & & $20-60$ & & & & $0-10$ & \\
\hline
\end{tabular}

Table 23 Marshall test result for RHASM

\begin{tabular}{|c|c|c|c|c|c|}
\hline Asphalt content (\%) & Compaction time & Stability $(\mathrm{kN})$ & $\begin{array}{c}\text { Flow value } \\
(0.01 \mathrm{~cm})\end{array}$ & Air void (\%) & Saturation (\%) \\
\hline \multirow{2}{*}{4.57} & 50 & 11.4 & 31 & 4.5 & 70.2 \\
\cline { 2 - 6 } & 75 & 14.6 & 30 & 3.9 & 73.3 \\
\hline \multirow{2}{*}{5.0} & 50 & 11.9 & 35 & 3.2 & 78.5 \\
\cline { 2 - 6 } & 75 & 13.6 & 30 & 3.0 & 79.6 \\
\cline { 2 - 6 } & 50 & 11.3 & 39 & 2.0 & 86.6 \\
\hline \multirow{2}{*}{5.5} & 75 & 14.2 & 33 & 2.0 & 86.6 \\
\cline { 2 - 6 } & 50 & 11.0 & 38 & 1.7 & 89.2 \\
\hline \multirow{2}{*}{6.0} & 55 & 9.6 & 38 & 1.5 & 90.3 \\
\cline { 2 - 6 } & 75 & $>7.35$ & 42 & 1.2 & 91.0 \\
\hline \multirow{2}{*}{6.5} & 75 & $20-40$ & $3-6$ & $70-85$ \\
\hline
\end{tabular}

Consequently, a recycling agent is required with a content determined by the weight of the recycled asphalt. In this test, the content was $11.7 \%$.

The Marshall test ${ }^{2)}$ was conducted to evaluate the gradation. Table 23 summarizes the results for compaction times of 50 and 75 . This table suggests that RHASM can satisfy the gradation requirement as a base even if the ratio of RAP is $100 \%$.

\section{CONCLUSIONS}

The followings are the main conclusions of this study to conduct to use reclaimed asphalt concretes fully.

1) All types of recycled materials that contain reclaimed asphalt concrete can satisfy the requirements for a base course and a subbase.

2) Recycled materials are sensitive to temperature and water. Thus, it is very important to decide the ratio of RAP for the recycled materials based on the local environmental conditions.
3) RCSM, RCESM and RHASM are more suitable than RGM for using large amounts of recycled asphalt concrete.

ACKNOWLEDGEMENT: This research was partly financed by Grant-in-Aid for Scientific Research (B) (No. 12555130) from the Ministry of Education and Science, Sports and Culture.

\section{REFERENCES}

1) John J. Emery: Asphalt concrete recycling in Canada, Transportation Research Record 1427, Washington D.C., pp. 38-46, 1993.

2) Japanese Road Association: Handbook for asphalt pavement test methods (in Japanese), 1989.

3) Japanese Road Association: Technical Guidelines for Recycled Base course Method (in Japanese), 1984.

4) Aviation Bureau, Ministry of Transport: Design criterion for concrete pavement in airport (in Japanese), pp.18-19, 1990. 


\section{アスファルトコンクリート発生材の路盤としての全量再生化}

\section{伍 石生・八谷好高・杉本浩一}

アスファルトコンクリートの再生は, 天然資源利用節約, コスト縮減, 省エネルギが可能となることか ら , わが国においてはますます主要な補修方法となってきている . 本研究では , 東京国際空港での廃アス ファルトコンクリートを 4 種類の路盤, すなわち粒状材, セメント安定処理材, セメントアスファルト乳 剂安定処理材, 加熱混合アスファルト安定処理材, として使用する場合の可能性について評価した . 室内 試験の結果から 1)用いた廃アスファルトコンクリートは上層路盤ならびに下層路盤として使用可能である こと，2)再生路盤材料は温度ならびに水分の影響を受けることが明らかになった． 